\title{
Soil microbial response to glucose and phosphorus addition under agricultural systems in the Brazilian Cerrado
}

\author{
ADÃO S. FERREIRA, MARIA AMELIA DOS SANTOS and GILBERTO F. CORRÊA \\ Instituto de Ciências Agrárias, Universidade Federal de Uberlândia, Rua Amazonas, s/n, 38400-902 Uberlândia, MG, Brasil \\ Manuscript received on May 25, 2012; accepted for publication on July 25, 2012
}

\begin{abstract}
Conventional tillage (CT) and no-tillage (NT) management systems alter soil nutrient availability and consequently modify soil microbial response to nutrient additions such as carbon (C) and phosphorus (P). The objective of this study is to evaluate microbial response to the addition of $\mathrm{C}$ (glucose) and $\mathrm{P}$ $\left(\mathrm{Na}_{2} \mathrm{HPO}_{4} \cdot 7 \mathrm{H}_{2} \mathrm{O}\right)$ under $\mathrm{CT}$ and $\mathrm{NT}$ in the brazilian Cerrado. In response to glucose addition, the NT system yielded higher microbial respiration rates and glucose consumption than the CT system. The best microbial response to $\mathrm{C}$ addition was after $0-12 \mathrm{~h}$ incubation in NT and $0-24 \mathrm{~h}$ in CT. The addition of P produced higher demand under CT than NT. After incubation, biochemical indicators such as microbial respiration, glucose consumption, dehydrogenase activity and metabolic yield confirmed the higher glucose demands under NT and higher phosphorus demands under CT. These results demonstrate that $\mathrm{C}$ and $\mathrm{P}$ addition alter significantly the microbial response, suggesting that soil microorganisms present nutrient differential demands between CT and NT management systems.
\end{abstract}

Key words: dehydrogenase, glucose assay, Michaelis-Menten equation, nutrient demands, incubation.

\section{INTRODUCTION}

Evaluation of soil microbial activity is of great importance in measuring the functional state of terrestrial ecosystems due to the fundamental role microorganisms play in energy flow, nutrient cycling and organic matter transformation. However, soil microbial activity is regulated by a 30 number of abiotic and biotic factors (Atlas and Bartha 1997, Han et al. 2007, Martins et al. 2011). Abiotic factors such as nutrient levels, temperature and moisture can typically be used to evaluate the potential responses of the microbial community. Evaluation of microbial activity by the amount of $\mathrm{CO}_{2}$ produced has been used as an indicator of soil metabolic response,

Correspondence to: Adão de Siqueira Ferreira

E-mail: adaosferreira@yahoo.com.br partly due to the simplicity of associated assays (Stotzky 1965, Hill et al. 2008). Therefore, metabolic response may be used as an additional attribute for predicting the impact of agricultural practices on terrestrial ecosystem function.

In tropical soils, there is evidence that soil microbial respiration is strongly regulated by carbon and phosphorus availability (Cleveland et al. 2002, Ilstedt et al. 2003, Ehlers et al. 2010). Due to their low soil content, carbon sources, such as glucose, sucrose and amino acids are usually the limiting factors of microbial activity (Cleveland et al. 2002, Hill et al. 2008). Under natural conditions, soluble carbon availability results from the decomposition of plant material which is affected by daily and seasonal fluctuations such as temperature and moisture 
(Nicolardot et al. 1994, Kirschbaum 2006, Vanhala et al. 2007, Van Meeteren et al. 2007). However, glucose addition to the soil has been utilized as a strategy for measuring the respiratory response of the soil microbial community (Shen and Bartha 1996, Chotte et al. 1998, Blagodatskaya et al. 2007, Hill et al. 2008). Studies have also demonstrated that soil phosphorus (P) availability regulates microbial activity due to microorganism demand for this nutrient (Cleveland et al. 2002, Ilstedt et al. 2006, Ferreira et al. 2008). In addition, there is a correlation between $\mathrm{P}$ content in soil solutions and other biochemical processes such as decomposition and mineralization of soil organic matter (Chotte et al. 1998, Saggar et al. 1998, Cleveland et al. 2002) and high sesquioxide content in older soils (Ilstedt et al. 2003, Gnankambary et al. 2008).

Many soil biochemical characteristics are frequently measured by assays under controlled conditions. For example, assays can be performed to quantify soil microbial response to environmental disturbance (Atlas and Bartha 1997) and thereby reveal the factors regulating microbial respiration (Raich and Tufekcioglu 2000) and establish the efficiency of substrate mineralization (e.g., glucose) by soil microorganisms (Shen and Bartha 1996 Ananyeva et al. 2008, Hill et al. 2008). Soil biochemical properties are important indicators in the evaluation of land-use (Chotte et al. 1998, Ananyeva et al. 2008, Hill et al. 2008, TrasarCepeda et al. 2008), including tillage systems.

Cerrado vegetation covers an area of about 204 million ha (approximately 22\% of the Brazilian territory) and is considered to be the country's second largest biome. Cerrado soils are used for a variety of agricultural activities, including grain production, stock raising and forestry. The predominant soil types in the region are Oxisols, highly weathered, deep, porous and have clay content above $15 \%$. They also generally hold small nutrient reserves for plant growth. Due to these characteristics, Oxisols have low cationic exchange capacity and high anionic adsorption, especially regarding phosphates.
In Brazil, few studies have been conducted on soil microbial activity in Cerrado regions under conventional tillage and no-tillage systems (Ferreira et al. 2008). Thus, the objective of this work was to evaluate soil microbial response to glucose and phosphorus addition under conventional tillage and no-tillage systems in the Brazilian Cerrado.

\section{MATERIALS AND METHODS}

The study was performed on soil samples of Cerrado typic acrustox from areas under conventional tillage (CT) and no-tillage (NT). The experiment was conducted in southern Brazil at the Agraria Science Institute of the Universidade Federal de Uberlândia. Annual precipitation in this region ranges from 1,500 to $1,700 \mathrm{~mm}$, and annual temperatures range from 12 to $34^{\circ} \mathrm{C}$, with a mean annual temperature of $22.7^{\circ} \mathrm{C}$. In the summer of 2008 , soil samples of $600 \mathrm{~cm}^{2}(20 \mathrm{~cm} \times 30 \mathrm{~cm})$ were taken down to a depth of $10 \mathrm{~cm}$. For each field sampling, four samples were combined to make composite samples which were transported to the laboratory in isothermic bags $\left(4^{\circ} \mathrm{C}\right)$. A portion of each sample was sieved $(<4 \mathrm{~mm})$, and moisture content was determined after $48 \mathrm{~h}$ at $105^{\circ} \mathrm{C}$. The remaining soil was stored at $4^{\circ} \mathrm{C}$ for a maximum of two weeks until the assay was analyzed. Additional physiochemical characteristics of the air-dried soil were analyzed (Table I). Microbial biomass carbon (Vance et al. 1987) and glucose content (Ferreira et al. 2008) were determined using moist soil, and the results were adjusted to the dry weight of the soil.

TABLE I

Some background soil characteristics.

\begin{tabular}{|c|c|c|}
\hline Soil characteristics & $\mathrm{CT}$ & NT \\
\hline Carbon organic $\left(\mathrm{g} . \mathrm{kg}^{-1}\right)$ & 11.1 & 45.2 \\
\hline Available phosphorus (mg.kg $\left.{ }^{-1}\right)$ & 3.6 & 40.1 \\
\hline Available potassium (mg.kg $\left.{ }^{-1}\right)$ & 11.0 & 335 \\
\hline $\mathrm{pH}$ in water $(1: 2)$ & 5.6 & 6.4 \\
\hline $\operatorname{MBC}\left(\mathrm{mg} \cdot \mathrm{kg}^{-1}\right)$ & 184 & 450 \\
\hline Total glucose (ug.kg ${ }^{-1}$ ) & 15.3 & 6.23 \\
\hline Dehydrogenase (ug INTF.g ${ }^{-1}$. soil h ${ }^{-1}$ ) & 15.2 & 21.3 \\
\hline
\end{tabular}


Soil microbial respiration assays were performed with glucose and phosphorus $\left(\mathrm{Na}_{2} \mathrm{HPO}_{4} \cdot 7 \mathrm{H}_{2} \mathrm{O}\right)$. Portions of moist soil (50 g) were placed in glass bottles $(300 \mathrm{~mL})$ containing glucose $(0,50,100$, 200, 400, 600, 800, 1,200 and 2,000 mg glu. $\mathrm{kg}^{-1}$ dry soil) and phosphorus nutrients (0, 50, 100, 200, 300, 400 and $600 \mathrm{mg} \mathrm{P.kg}{ }^{-1}$ dry soil). Four replicates were performed for each experiment. Distilled water was used to adjust soil moisture content to $60 \%$ of water-holding capacity. The bottles were incubated at room temperature which ranged from $21^{\circ}$ to $23^{\circ} \mathrm{C}$ and averaged $22.3^{\circ} \mathrm{C}$. Microbial respiration response to glucose addition was measured after incubation periods of $0-12 \mathrm{~h}$, 0 - 24h, 12 - 24h and 24 - 48h. Respiration response to phosphorus addition was evaluated after 3 and 7 days of incubation at room temperature.

Microbial respiration was determined by measuring released $\mathrm{CO}_{2}$ (Stotzky 1965). This assay was carried out in glass bottles $(300 \mathrm{~mL})$ containing soil and plastic cups with $5 \mathrm{~mL}$ of sodium hydroxide $\left(1 \mathrm{~mol} \mathrm{~L}^{-1}\right)$. The $\mathrm{C}-\mathrm{CO}_{2}$ collected in the alkaline solution was determined by titration of the residual $\mathrm{NaOH}$ with chloride acid $\left(0.25 \mathrm{~mol} . \mathrm{L}^{-1}\right)$ after the addition of $2.5 \mathrm{~mL}$ of $\mathrm{BaCl}_{2} \cdot 2 \mathrm{H}_{2} \mathrm{O}\left(1 \mathrm{~mol} . \mathrm{L}^{-1}\right)$ and phenolphthalein indicator. The $\mathrm{C}-\mathrm{CO}_{2}$ produced was expressed in $\mathrm{mg} \mathrm{C}-\mathrm{CO}_{2} \cdot \mathrm{kg}^{-1}$ dry soil.

Soil samples $(10 \mathrm{~g})$ were transferred to Falcon bottles $(50 \mathrm{~mL})$, and glucose was added as described above. An aliquot of sugar in solution was used for each treatment. Soil moisture was adjusted to $60 \%$ of water-holding capacity with distilled water. The bottles were incubated at room temperature for $0,6,12,18$ and $24 \mathrm{~h}$. After incubation, the glucose content of each treatment was extracted as described in a previous study (Ferreira et al. 2008). The bottles were transferred to a microwave oven and exposed to electromagnetic irradiation for 1 $\min \left(1.6210^{5} \mathrm{~J}\right)$. Then, $15 \mathrm{~mL}$ of $\mathrm{NaCl}(0.5 \%)$ was added and the bottles were agitated for $20 \mathrm{~min}$ at $70^{\circ} \mathrm{C}$. The soil solution was filtered (Whatman $\mathrm{n} \#$. 40 paper filter) and centrifuged at $8,000 \mathrm{x}$ g for 10 min. An aliquot $(25-250 \mathrm{uL})$ of the supernatant was removed to determine the amount of glucose remaining in the soil.

Glucose content was determined by the glucose oxidase-peroxidase method, following the recommendations of the kit manufacturer (Sigma, USA). A standard curve was generated with known amounts of glucose $\left(0,2,4,8,16\right.$ and 32 ug.mL $\left.\mathrm{mL}^{-1}\right)$. The absorbance of the samples was measured with a cuvette in a spectrophotometer at $500 \mathrm{~nm}$.

Dehydrogenase activity was measured by reduction of 2-p-iodo-3-nitrophenyl 5-phenyl tetrazolium chloride (INT) to iodonitrophenyl formazan (INTF) with modification to the method reported by Von Mersi and Schinner (1991). Portions of moist soil (1 g) were transferred to Falcon bottles $(50 \mathrm{~mL})$ containing $1.0 \mathrm{~mL}$ Tris (1 mol.L $\mathrm{L}^{-1}, \mathrm{pH}$ 7.0) and $1 \mathrm{~mL}$ INT (10 mmol. $\mathrm{L}^{-1}$ in $2 \% \mathrm{~N}, \mathrm{~N}$-dimetilphormamide). The mixture was incubated at $37^{\circ} \mathrm{C}$ for $24 \mathrm{~h}$. After incubation, INTF was extracted using $10 \mathrm{~mL}$ of N,N-dimetilphormamide: ethanol $(1: 1)$ and then agitated and rested for $20 \mathrm{~min}$. An aliquot of $2 \mathrm{~mL}$ was centrifuged at $6,000 \times \mathrm{g}$ for $5 \mathrm{~min}$ and the amount of INTF in the supernatant was measured by spectrophometry at $464 \mathrm{~nm}$. An INTF standard curve was used to determine dehydrogenase activity in the soil samples.

The induced response of microbial activity was performed under assay conditions with the addition of carbon (1.6 g C.kg-1 dry soil), nitrogen (200 mg N.kg ${ }^{-1}$ dry soil), and phosphorus (400 mg P. $\mathrm{kg}^{-1}$ dry soil) to the soil. Carbon, nitrogen and phosphorus sources were glucose, ammonium nitrate $\left(\mathrm{NH}_{4} \mathrm{NO}_{3}\right)$ and sodium phosphate $\left(\mathrm{Na}_{2} \mathrm{HPO}_{4} \cdot 7 \mathrm{H}_{2} \mathrm{O}\right)$, respectively. The nutrient treatments were: (1) control, (2) C, (3) P, (4) C + P, (5) N, and (6) $\mathrm{C}+\mathrm{N}+\mathrm{P}$. Metabolic yield $(\mathrm{Y})$ of the soil microbes was obtained from the ratio of substrate carbon oxidation to $\mathrm{CO}_{2}$ and carbon assimilation by the soil microbial community (Shen and Bartha 1996) during the $24 \mathrm{~h}$ incubation period. 
Results were submitted to factorial ANOVA and the differences among treatment means were tested at a $5 \%$ probability level. Regression analysis of the Michaelis-Menten equation was performed to determine microbial response to nutrient additions, where

$$
\mathrm{MR}=\left(\mathrm{MR}_{\max } \mathrm{N}\right) /\left(\mathrm{k}_{\mathrm{m}}+\mathrm{N}\right)
$$

$\mathrm{MR}$ is the microbial respiration rate $(\mathrm{mgC}-$ $\mathrm{CO}_{2} \cdot \mathrm{kg}^{-1}$ ) per day or hour, $\mathrm{MR}_{\max }$ is the maximum rate of microbial respiration, $\mathrm{N}$ is nutrient added (mg N. $\mathrm{kg}^{-1}$ dry soil, either glucose or phosphorus) and $\mathrm{k}_{\mathrm{m}}$ is the Michaelis-Menten constant (mg N.kg-1 dry soil). The kinetic response parameters were limited to a probability level of $5 \%$.

\section{RESULTS}

The highest microbial respiration response to glucose addition was observed in soil samples incubated for $24 \mathrm{~h}$ (Fig. 1B). However, both soils showed a differential response when the Michaelis-Menten equation was applied. In NT, best fit was observed for the period of $0-12 \mathrm{~h}$ (Fig. 1A), with values of $\mathrm{MR}_{\max }=130 \mathrm{mg} \mathrm{C}-\mathrm{CO}_{2} \cdot \mathrm{h}^{-1} \mathrm{~kg}^{-1}$ dry soil and $\mathrm{km}=$ $693 \mathrm{mg}$ glu. $\mathrm{kg}^{-1}$ dry soil $\left(\mathrm{R}_{\text {ajusted }}^{2}=0.981\right)$. In CT, the values were $\mathrm{MR}_{\max }=36.5 \mathrm{mg} \mathrm{C}-\mathrm{CO}_{2} \cdot \mathrm{h}^{-1} \cdot \mathrm{kg}^{-1}$ dry soil and $\mathrm{km}=178 \mathrm{mg}$ glu. $\mathrm{kg}^{-1}$.dry soil $\left(\mathrm{R}^{2}\right.$ ajusted $=0.961)$ for the same incubation period. In CT, the best fit was observed for the incubation period of $0-24 \mathrm{~h}$ (Fig. 1B) with values of $\mathrm{MR}_{\max }=126 \mathrm{mg}$ $\mathrm{C}-\mathrm{CO}_{2} \cdot \mathrm{h}^{-1} \cdot \mathrm{kg}^{-1}$.dry soil and $\mathrm{km}=845 \mathrm{mg}$ glu. $\mathrm{kg}^{-1}$.

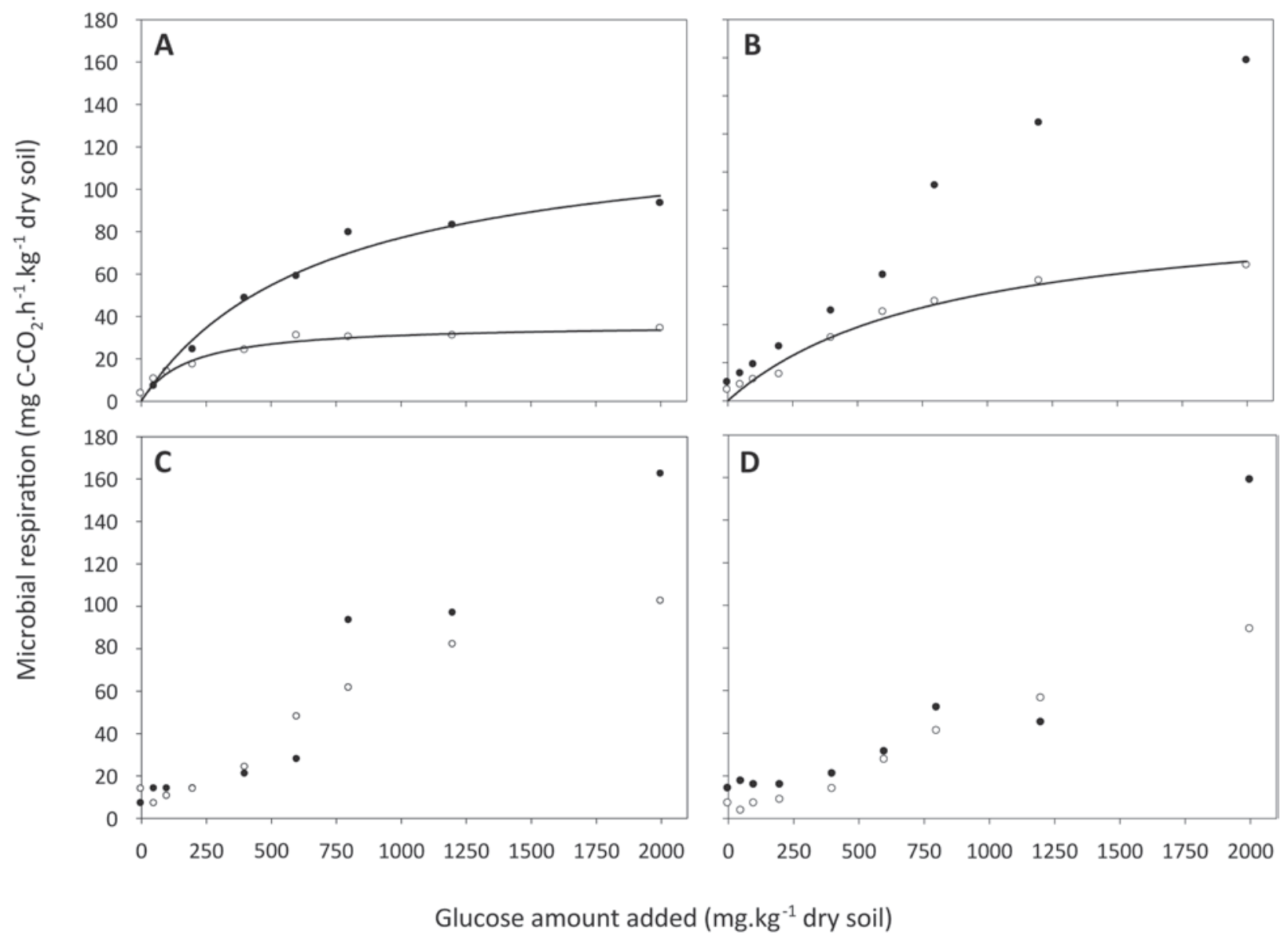

Fig. 1 - Microbial respiration of soils in response to addition of glucose and incubation period under NT $(\bullet)$ and CT (०) systems. A, 0-12h of incubation. B, 0-24h of incubation. C, 12-24h of incubation. D, 24-48h of incubation. Data represent the mean of four assays under conditions of room temperature. The lines in A and B show the best fit to the Michaelis-Menten equation to a probability level of $5 \%(n=4)$. 
dry soil $\left(\mathrm{R}_{\text {ajusted }}^{2}=0.978\right)$. Regression analysis did not yield a good fit for the other incubation periods when the Michaelis-Menten equation was applied at $5 \%$ probability (Fig. 1C and 1D).

Glucose consumption was higher in NT than in CT for all assay periods (Fig. 2). After $24 \mathrm{~h}$ of incubation, glucose had been consumed in all NT treatments, including the treatment with 2,000 mg glucose $\mathrm{kg}^{-1}$ dry soil. Remaining glucose was higher for all CT assays than it was for NT.

Figure 3 shows the kinetic parameters obtained from the Michaelis-Menten equation for microbial respiration in both soils with added phosphorus (Fig. 3). Results showed high regression coefficients

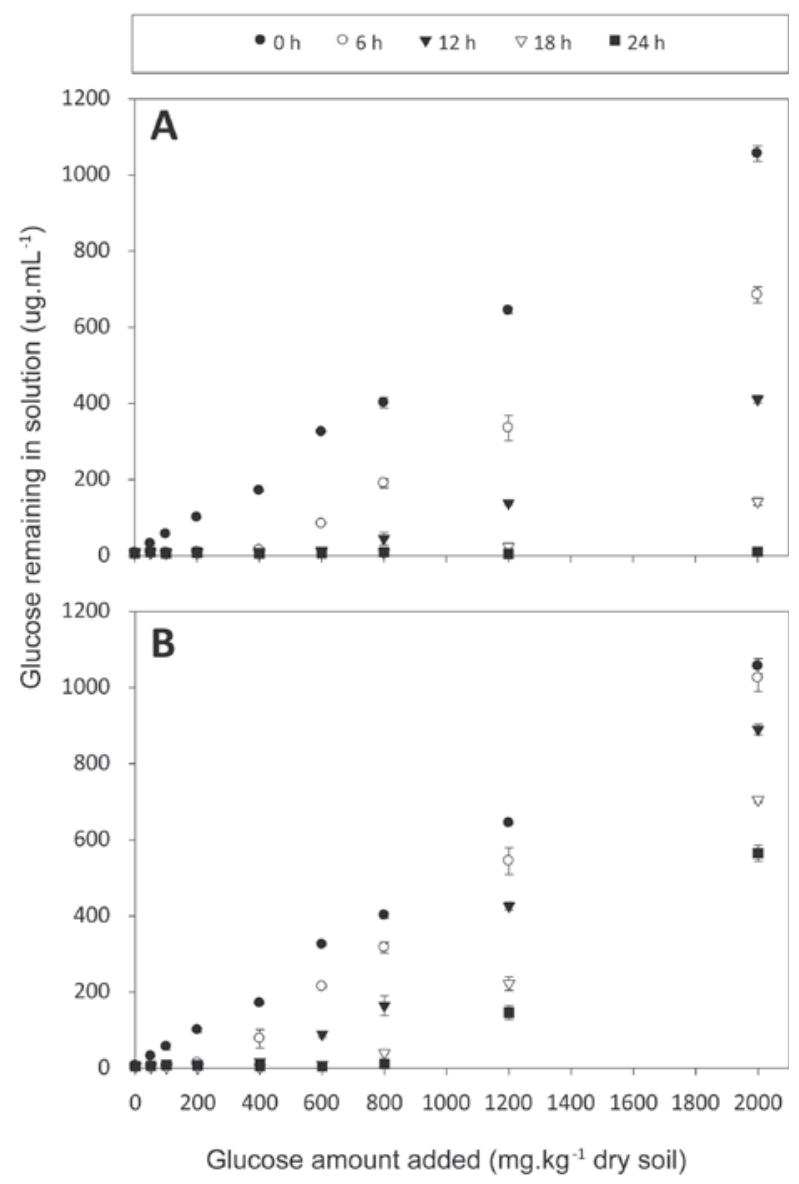

Fig. 2 - Glucose remaining in soil solution extracted with $\mathrm{NaCl}$ $(0.5 \%)$ under incubation conditions for $0,6,12,18$ and $24 \mathrm{~h}$ at room temperature. Pattern the glucose consumption in NT (A) and CT (B). The bars show the confidence intervals to $95 \%$ probability $(n=3)$. for both soils (with $\mathrm{R}^{2}$ higher in $\mathrm{CT}$ ). $\mathrm{MR}_{\max }$ in $\mathrm{CT}$ was about 2.1 times higher than in NT; however, $\mathrm{k}_{\mathrm{m}}$ of CT was about 1.5 times lower. The results clearly revealed that phosphorus additions yielded significant microbial respiration gains in NT $\left(>\mathrm{MR}_{\max }\right)$, while significant $\mathrm{P}$ demand was observed in CT under laboratory assay conditions $\left(<\mathrm{k}_{\mathrm{m}}\right)$.

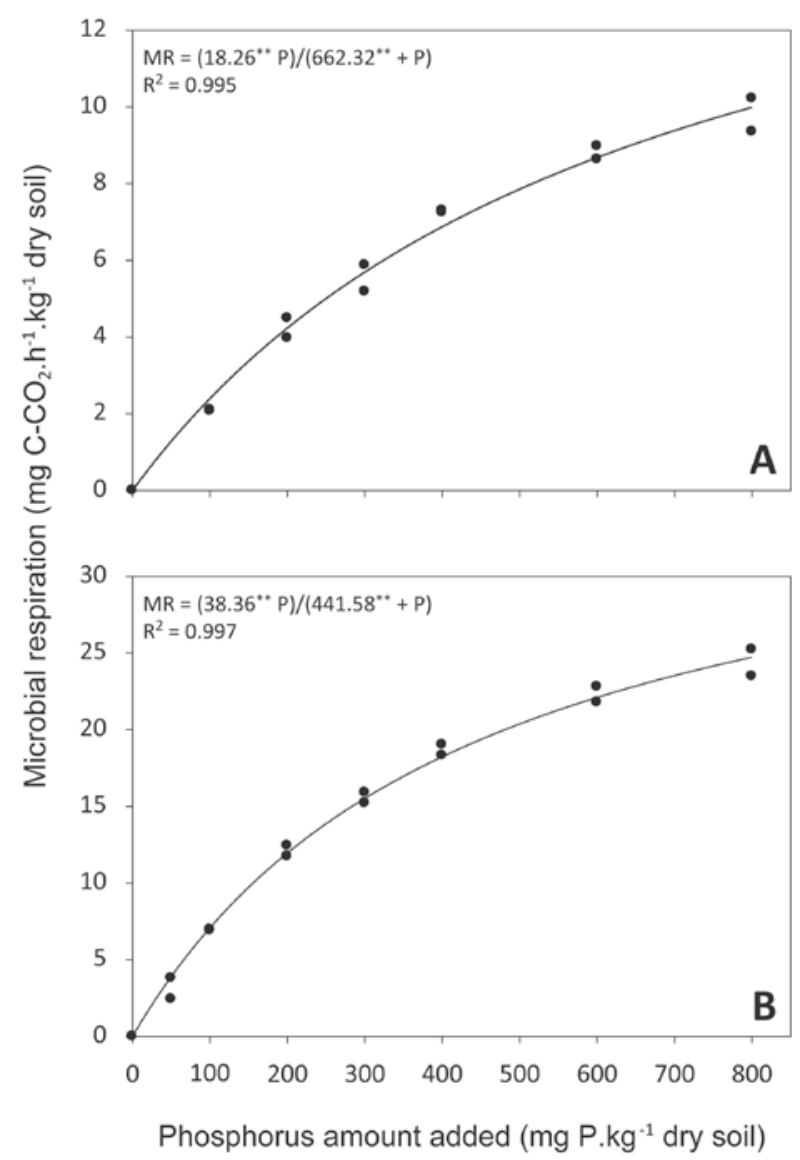

Fig. 3 - Microbial respiration in response to phosphorus addition in soils. The soil samples are represented with NT (A) and CT (B). The signs $(* *)$ show that kinetic parameters to the Michaelis- Menten are significantly fitted at a probability level of $5 \%(\mathrm{~N}=2)$.

Microbial respiration, dehydrogenase activity and metabolic yield after the addition of glucose $(\mathrm{G})$, phosphorus $(\mathrm{P})$ and nitrogen $(\mathrm{N})$ are shown in Table II. Except for dehydrogenase activity in CT, glucose addition to both soils increased metabolic response compared to the control. There was no metabolic response (microbial respiration and 
dehydrogenase activity) for soils in the treatments with $\mathrm{P}$ and $\mathrm{N}$ after $24 \mathrm{~h}$ of incubation, when analyzed separately. However, metabolic response increased in the CT $(\mathrm{G}+\mathrm{P}$ treatment $)$, whereas this increase was not observed in NT. In the treatment with $\mathrm{G}+\mathrm{P}+\mathrm{N}$, increases in microbial respiration and dehydrogenase activity were observed.
The results (Table II) also show that metabolic yield increased when phosphorus was applied, with substantial increases in CT. Compared to the $\mathrm{P}$ treatment, $\mathrm{N}$ addition did not alter metabolic yield, although there was an additional increase when $\mathrm{N}$ was applied together with glucose and phosphorus (treatment $\mathrm{G}+\mathrm{P}+\mathrm{N}$ ).

TABLE II

Microbial responses to nutrient addition under conventional tillage (CT) and no-tillage (NT) systems.

\begin{tabular}{|c|c|c|c|c|c|c|}
\hline \multirow[t]{2}{*}{ Treatment } & \multicolumn{2}{|c|}{$\begin{array}{c}\text { Microbial respiration } \\
\left(\mathrm{mg} \mathrm{C}-\mathrm{CO}_{2} \cdot \mathrm{kg}^{-1} \text { dry soil) }\right.\end{array}$} & \multicolumn{2}{|c|}{$\begin{array}{c}\text { Dehydrogenase } \\
\text { (ug INTF.g } \text { g }^{-1} \text { dry soil. }{ }^{-1} \text { ) }\end{array}$} & \multicolumn{2}{|c|}{ Metabolic yield (Y) } \\
\hline & $\mathrm{CT}$ & NT & $\mathrm{CT}$ & NT & $\mathrm{CT}$ & NT \\
\hline Control & $17.4 \mathrm{~d}$ & $19.0 \mathrm{c}$ & $16.8 \mathrm{c}$ & $18.7 \mathrm{c}$ & -- & -- \\
\hline G & $98.8 \mathrm{~b}$ & $270.0 \mathrm{~b}$ & $19.0 \mathrm{c}$ & $25.0 \mathrm{~b}$ & 0.077 & $0.225^{*}$ \\
\hline$P$ & $36.4 \mathrm{~d}$ & $35.2 \mathrm{c}$ & $19.2 \mathrm{bc}$ & $19.8 \mathrm{c}$ & -- & -- \\
\hline$G+P$ & $169.0 \mathrm{c}$ & $269.0 \mathrm{~b}$ & $22.6 \mathrm{~b}$ & $26.5 \mathrm{~b}$ & 0.230 & $0.296^{*}$ \\
\hline $\mathrm{N}$ & $17.4 \mathrm{~d}$ & $23.6 \mathrm{c}$ & $16.3 \mathrm{c}$ & $18.3 \mathrm{c}$ & -- & -- \\
\hline $\mathrm{G}+\mathrm{P}+\mathrm{N}$ & $289.0 \mathrm{a}$ & $350.4 \mathrm{a}$ & $28.6 \mathrm{a}$ & $28.3 \mathrm{a}$ & 0.247 & $0.309 *$ \\
\hline
\end{tabular}

Treatments with the same letter on columns no differ between them in relation the variables (microbial respiration and dehydrogenase), when applied the Tukey test at the $95 \%$ probability.

* this sign shows that there are significant differences of Y between CT and NT in each treatment, when applied the orthogonal contrast test at the $95 \%$ probability.

\section{DISCUSSION}

In this study, an applicable approach for evaluating the soil microbial response of two tillage systems from a region in the Brazilian Cerrado was demonstrated. Changes in microbial respiration, glucose consumption and metabolic yield were observed in response to glucose and phosphorus additions. Some studies have reported on soil microbial response to glucose and phosphorus addition under laboratory assay conditions, providing insight into the nutritional demands of different soils (Saggar et al. 1998, Cleveland et al. 2002, Ilstedt and Singh 2005, Boddy et al. 2008, Schneckenberger et al. 2008).

In response to the addition of glucose, microbial respiration was consistently different between tillage systems (Fig. 1), revealing that NT had higher demand for soluble carbon as an energy source. This observation was also confirmed by sugar consumption during incubation (Fig. 2). Higher microbial respiration response in NT can also be related to the amount of available nutrients in this soil (Table I). This study showed that the fit of the Michaelis-Menten equation depended on incubation period, as observed in CT (Fig. 1B). For NT, fit was not determined for the $0-24 \mathrm{~h}$ incubation period due to the absence of significant kinetic parameters. The $0-12 \mathrm{~h}$ incubation period resulted in $\mathrm{k}_{\mathrm{m}}$ that was 3.89 times higher for NT than it was for CT. This equation has been used to indicate the kinetic response to low molecular weight compound soil additions such as glucose and amino acids (Vinolas et al. 2001, van Hees et al. 2005, Boddy et al. 2008, Schneckenberger et al. 2008). Here, it was demonstrated that the MichaelisMenten equation can be of great importance in evaluating soil microorganism response to glucose addition under different agricultural systems. 
Measuring glucose content in the soil using the glucose oxidase-peroxidase method was quite suitable. About $94 \%$ of the glucose applied to the soil (control) was recovered in the extraction solution $(0.5$ $\%$ sodium chloride). Some studies, such as Boddy et al. (2008) and Nambu et al. (2008), have determined soil glucose content by this method, but have not provided details on their extraction and determination methods. Finding soil glucose content by this method could be important for studies evaluating the utilization efficiency of sugar as a carbon and energy source for soil microorganisms. In addition, glucose assays have been used to evaluate soluble carbon (C) mineralization models (Shen and Bartha 1996, van Hees et al. 2005), organic C turnover (Chotte et al. 1998, Boddy et al. 2008), and soil microbial biomass C estimation (Anderson and Domsch 1978).

This study demonstrated the microorganism response to the addition of $\mathrm{P}$ to the soil (Fig. 3A and $3 \mathrm{~B}$ ). The effect of phosphorus addition on microbial response was substantial under $\mathrm{CT}$ when analyzed with the Michaelis-Menten regression equation, demonstrating that microbial demand for available phosphorus is high under CT. For many old soils in tropical ecosystems, phosphorus is usually believed to be the most limiting nutrient due to high nutritional demand of plants and microorganisms (Cleveland et al. 2002). In many terrestrial ecosystems, high $\mathrm{P}$ demand and its low availability in soils provide solid arguments that this nutrient acts as a metabolic regulator of microbial activity (Crews et al. 1995, Cleveland et al. 2002, Ilstedt et al. 2006).

In the final analysis of the assays, it was confirmed that differences exist between soils regarding metabolic response to nutrient additions (Table II). In the $24 \mathrm{~h}$ incubation assay, $\mathrm{P}$ addition produced greater metabolic response increases for CT. However, for NT, metabolic response increased after glucose addition. $\mathrm{N}$ addition did not yield any metabolic response increases. However, there were additional increases in metabolic response when
$\mathrm{N}$ was added together with $\mathrm{G}$ and $\mathrm{P}$. Addition of $\mathrm{P}$ increased soil metabolic yield, suggesting that there was a greater efficiency in glucose utilization and showing greater capacity of microorganisms to mineralize the carbon soluble. These results also suggest soil microbial activity is strongly regulated $\mathrm{P}$ in the soil, but the microorganism response depends on land-use systems. However, more studies should be undertaken to elucidate the mechanisms involved in the action of $\mathrm{P}$ in soil, especially in tropical ecosystems.

This study also showed that microbial respiration, dehydrogenase activity and metabolic yield can be used as indicators to measure soil metabolic responses to nutrient additions. Particularly, dehydrogenase enzyme has been linked to greater carbon availability for microorganisms given that its activity is directly linked to intracellular transformations of organic compounds (Pajares et al. 2011) with consequent implications for soil processes such as the mineralization of organic matter (Pankhurst et al. 1998, Lagomarsino et al. 2009).

Quantifying and understanding the dependence of soil microbial activity on nutrients remains a key focus for investigating soil ecosystem function. In particular, the quest for reference values of soil metabolism associated with nutrient availability has been ongoing due to the fundamental role nutrients play in regulating plant and soil microorganism growth (Coody et al. 1986, Kouno et al. 2002). In Brazil and specifically in the Cerrado, little information regarding microbial response has been generated (Ferreira et al. 2008) which suggests a need for more studies to increase knowledge of biological transformations in the soil.

\section{CONCLUSIONS}

In response to glucose addition, microbial respiration rates $\left(\mathrm{C}-\mathrm{CO}_{2}\right.$ efflux $)$ were higher with $\mathrm{NT}$ than with $\mathrm{CT}$ in typic acrustox of the Cerrado. A similar response was observed with glucose consumption under laboratory assay conditions, 
suggesting that NT systems require more carbon than CT systems. Microbial response to P addition was higher in the CT system than in the NT system, implying that phosphorus played a greater role in soil microbial respiration in CT than in NT. Biochemical indicators such as dehydrogenase activity, microbial respiration and metabolic yield confirmed these greater glucose demands in NT and phosphorus in $\mathrm{CT}$ after an incubation period of $24 \mathrm{~h}$ under laboratory assay conditions.

\section{ACKNOWLEDGMENTS}

The study was financially supported by the Fundação de Amparo à Pesquisa do Estado de Minas Gerais (FAPEMIG, Projects CAG-APQ-02889-09 and CAG - APQ-00798-09).

\section{RESUMO}

Os sistemas convencional (SC) e plantio direto (SPD) alteram a disponibilidade de nutrientes no solo e, consequentemente, modificam a resposta da microbiota do solo à adição de nutrientes tais como carbono (C) e fósforo $(\mathrm{P})$. $\mathrm{O}$ objetivo deste estudo foi avaliar a resposta da microbiota do solo à adição de $\mathrm{C}$ (glicose) e $\mathrm{P}$ $\left(\mathrm{Na}_{2} \mathrm{HPO}_{4} \cdot 7 \mathrm{H}_{2} \mathrm{O}\right)$ sob os $\mathrm{SC}$ e SPD no Cerrado brasileiro. Em resposta à adição de glicose, o sistema SPD apresentou maior taxa de respiração microbiana e consumo de glicose do que o SC. A melhor resposta da microbiota à adição de carbono foi após 12 horas de incubação no SPD e 24 horas no SC. A adição de P produziu um maior efeito sob SC do que SPD. Após a incubação, os indicadores bioquímicos, como respiração microbiana, consumo de glicose, atividade de desidrogenase e rendimento metabólico, confirmaram a maior demanda de glicose em SPD e de P em SC. Esses resultados demonstraram que as adições de $\mathrm{C}$ e $\mathrm{P}$ alteram significativamente a resposta microbiana do solo, sugerindo que os microorganismos do solo apresentam uma demanda diferencial de nutrientes entre os sistemas SC e SPD.

Palavras-chave: desidrogenase, ensaio de glicose, equação de Michaelis-Menten, demanda de nutrientes, incubação.

\section{REFERENCES}

ANANYEVA ND, SUSYAN EA, CHERnOVA OV AND WirTh S. 2008. Microbial respiration activities of soils from different climatic regions of European Russia. Eur J Soil Biol 44: 147-157.

ANDERSON JPE AND DOMSCH KH. 1978. A physiological method for the quantitative measurement of microbial biomass in soils. Soil Biol Biochem 10: 215-221.

ATLAS RM AND BARTHA R. 1997. Microbial Ecology: Fundamentals and Applications: Benjamin Cummings, 533 p.

BlagodatsKaya EV, BLAGODATSKY SA, ANDERSON TH AND KuZYAKOV Y. 2007. Priming effects in Chernozem induced by glucose and $\mathrm{N}$ in relation to microbial growth strategies. Appl Soil Ecol 37: 95-105.

Boddy E, Roberts P, Hill PW, Farrar J AND JONES DL. 2008. Turnover of low molecular weight dissolved organic $\mathrm{C}$ (DOC) and microbial $\mathrm{C}$ exhibit different temperature sensitivities in Arctic tundra soils. Soil Biol Biochem 40: 1557-1566.

ChotTe JL, LAdD JN AND AMATo M. 1998. Sites of microbial assimilation, and turnover of soluble and particulate ${ }^{14} \mathrm{C}$-labelled substrates decomposing in a clay soil. Soil Biol Biochem 30: 205-218.

Cleveland CC, TOWNSEND AR AND SCHMIDT SK. 2002. Phosphorus limitation of microbial processes in moist tropical forests: evidence from short-term laboratory incubations and field studies. Ecosystems 5: 680-691.

CoOdy PN, Sommers LE AND Nelson DW. 1986. Kinetics of glucose uptake by soil microorganisms. Soil Biol Biochem 18: 283-289.

Crews TE, Kitayama K, Fownes JH, Riley RH, Herbert DA, Mueller-Dombois D AND VitouseK PM. 1995 Changes in soil phosphorus fractions and ecosystem dynamics across a long chronosequence in Hawaii. Ecol 76: 1407-1424.

EHLERS K, BAKKEN LR, FrostegÅrd Å, Frossard E AND BÜNEMANN EK. 2010. Phosphorus limitation in a Ferralsol: impact on microbial activity and cell internal $\mathrm{P}$ pools. Soil Biol Biochem 42: 558-566.

FERrEIRA AS, OliveIRA RS, SANTOS MA AND BORGES EM. 2008. Respiratory activity of soil microbiota and glucose content in response to phosphorus addition in Cerrado soil-Brazil. Rev Bras Ci Solo 32: 1891-1897.

Gnankambary Z, Ilstedt U, Nyberg G, Hien V and MALMER A. 2008. Nitrogen and phosphorus limitation of soil microbial respiration in two tropical agroforestry parklands in the south-Sudanese zone of Burkina Faso: the effects of tree canopy and fertilization. Soil Biol Biochem 40: 350-359.

HaN G, Zhou G, XU Z, YANG Y, LiU J AND Shi K. 2007. Biotic and abiotic factors controlling the spatial and temporal variation of soil respiration in an agricultural ecosystem. Soil Biol Biochem 39: 418-425.

HILl PW, FARRAR JF AND JONES DL. 2008. Decoupling of microbial glucose uptake and mineralization in soil. Soil Biol Biochem 40: 616-624. 
Ilstedt U, Giesler R, NoRdgren A ANd Malmer A. 2003. Changes in soil chemical and microbial properties after a wildfire in a tropical rainforest in Sabah, Malaysia. Soil Biol Biochem 35: 1071-1078.

ILsTedt U, Nordgren A AND Malmer A. 2006. Soil chemical and microbial properties after disturbance by crawler tractors in a Malaysian forest plantation. Forest Ecol Manage 225: 313-319.

ILSTEDT U AND SINGH S. 2005. Nitrogen and phosphorus limitations of microbial respiration in a tropical phosphorus-fixing acrisol (ultisol) compared with organic compost. Soil Biol Biochem 37: 1407-1410.

KIRSCHBAUM MUF. 2006. The temperature dependence of organic-matter decomposition still a topic of debate. Soil Biol Biochem 38: 2510-2518.

KounO K, WU J AND BROOKES PC. 2002. Turnover of biomass $\mathrm{C}$ and $\mathrm{P}$ in soil following incorporation of glucose or ryegrass. Soil Biol Biochem 34: 617-622.

Lagomarsino A, Moscatelli M, Di Tizio A, Mancinelli R, GRego S AND MARINARI S. 2009. Soil biochemical indicators as a tool to assess the short-term impact of agricultural management on changes in organic $\mathrm{C}$ in a mediterranean environment. Ecol Indic 9: 518-527.

Martins PF, Carvalho G, Gratão PL, Dourado MN, PILEgGi MA, ARAÚJo WL AND AZEVEdo RA. 2011. Effects of the herbicides acetochlor and metolachlor on antioxidant enzymes in soil bacteria. Process Biochem 46:1186-1195.

Nambu K, Van HeEs PAW, Jones DL, Vinogradoff S AND LUNDSTRÖM US. 2008. Composition of organic solutes and respiration in soils derived from alkaline and non-alkaline parent materials. Geoderma 144: 468-477.

Nicolardot B, Fauvet G and Cheneby D. 1994. Carbon and nitrogen cycling through soil microbial biomass at various temperatures. Soil Biol Biochem 26: 253-261.

Pajares S, Gallardo JF, Nasciandaro G, Ceccanti B AND ETCHEVERS JD. 2011. Enzyme activity as an indicator of soil quality changes in degraded cultivated acrisols in the mexican trans-volcanic belt. Land Degrad Dev 22: 373-381.

PANKHURST CE, Rogers SL AND GUPTA VVSR. 1998. Microbial parameters for monitoring soil pollution. In: LYNCH JM AND WISEMAN A (Eds), Environmental biomonitoring: The biotechnology ecotoxicology interface Cambridge Univ.Press/OCDE, Cambridge.cite, p. 46-69.
RAICH S AND TUfEKCIOGLU A. 2000. Vegetation and soil respiration: correlations and controls. Biogeochem 48: 71-90.

SAgGar S, PARfitt RL, SAlt G AND SkinNer MF. 1998. Carbon and phosphorus transformations during decomposition of pine forest floor with different phosphorus status. Biol Fertil Soils 27: 197-204.

SCHNECKENBERGER K, DEMIN D, STAHr K AND KuZYAKOV Y. 2008. Microbial utilization and mineralization of [14C] glucose added in six orders of concentration to soil. Soil Biol Biochem 40: 1981-1988.

SHEN J AND BARTHA R. 1996. Metabolic efficiency and turnover of soil microbial communities in biodegradation tests. Appl Environ Microbiol 62: 2411-2415.

STOTZKY G. 1965. Microbial respiration. In: Black CA (Ed), Methods of soil analysis: Madison: American Society of Agronomy 2: 1551-1572.

Trasar-CEPEDA C, LeIrós MC, SEOANE S AND GIL-Sotres F. 2008. Biochemical properties of soils under crop rotation. Appl Soil Ecol 39: 133-143.

Van Hees PaW, Jones DL, Finlay R, Godbold DL and LUNDSTRÖM US. 2005. The carbon we do not see - the impact of low molecular weight compounds on carbon dynamics and respiration in forest soils: a review. Soil Biol Biochem 37: 1-13.

Van Meeteren M, Tietema A AND Westerveld J. 2007. Regulation of microbial carbon, nitrogen, and phosphorus transformations by temperature and moisture during decomposition of Calluna vulgaris litter. Biol Fertil Soils 44: 103-112.

VANCE ED, BROOKES PC AND JENKINSON DS. 1987. An extraction method for measuring soil microbial biomass C. Soil Biol Biochem 19: 703-707.

VANHala P, Karhu K, TuOmi M, SONNINEN E, JUngner H, FRITZE H AND LISKI J. 2007. Old soil carbon is more temperature sensitive than the young in an agricultural field. Soil Biol Biochem 39: 2967-2970.

VINOLAS LC, HeALEY JR AND JONES DL. 2001. Kinetics of soil microbial uptake of free amino acids. Biol Fertil Soils 33: 67-74.

VON MERSI W AND SCHINNER F. 1991. An improved and accurate method for determining the dehydrogenase activity of soil with iodonitrotetrazolium choride. Biol Fertil Soils 11: 216-220. 